\title{
Fire endurance of steel reinforced fly ash geopolymer concrete elements
}

\author{
Prabir Kumar Sarker ${ }^{\mathrm{a},}$, , Simon Mcbeath ${ }^{\mathrm{b}}$ \\ a Department of Civil Engineering, Curtin University, GPO Box U1987, Perth, WA 6845, Australia. \\ email:p.sarker@curtin.edu.au \\ ${ }^{\mathrm{b}}$ Infra Tech Pty Ltd, Perth, Western Australia. \\ email: simon.mcbeath@infratecheng.com \\ *Corresponding author: Tel +61 89266 7568; Fax +61 89266 2681;
}

As a new alternative to OPC, investigation into the fire endurance of geopolymer concrete is of utmost importance in order to ensure safety. Geopolymer and OPC concrete panels of 125 to $175 \mathrm{~mm}$ thickness containing a layer of steel mesh were exposed to fire for two hours. Test results show higher heat transfer rate and less cracking and spalling in the geopolymer concrete specimens. The residual load capacity was between 61 and $71 \%$ for the geopolymer and between 50 and 53\% for the OPC concrete panels. Thus, the reinforced geopolymer concrete elements demonstrated superior fire endurance than the OPC counterparts.

Keywords: Fly ash, fire endurance, reinforced geopolymer concrete, residual strength, spalling.

\section{Introduction}

The global demand of concrete is increasing with the increasing need for constructions. Ordinary Portland cement (OPC) has long been used as the traditional binder for concrete. However, alternative binders utilising industrial by-products are required in order to reduce the carbon footprint of concrete. It is known that about one tonne of carbon dioxide is emitted into atmosphere in the production of one tonne of cement. Geopolymer is an 
emerging alternative binder that uses industrial by-products instead of cement. A base material such as fly ash which is rich in silicon and aluminum is reacted by an alkaline solution to produce the geopolymer binder. The base material for geopolymerisation can be a single material or combination of different materials. Materials such as fly ash [1-4], metakaolin [5] and blast furnace slag [6-7] are possible to use as the base material for geopolymer binders. Blending of fly ash with a small quantity of calcium bearing materials have also been used to enhance the early-age properties at room temperature curing conditions $[2,8,9]$. The reaction products were found to be different depending on the type of the base material and the activating alkaline liquids used for geopolymerisation [10]. Among these common base materials, low-calcium fly ash has been found as the most suitable principal binder for geopolymer concrete. Coal-fired power stations worldwide generate large amount of fly ash as a by-product. A substantial part of this fly ash remains unused after different conventional methods of uses. The unused fly ash causes environmental pollutions and the ash ponds occupy vast area of costly land that could be otherwise used for productive purposes. This accumulated volume of the unused fly ash in various countries can be properly utilized as the base material for producing low-emission geopolymer concrete. This can help significantly reduce the carbon footprint of concrete

Results of the ongoing studies on various engineering properties [8-11] showed the potential use of fly ash based geopolymer concrete as a construction material. As a new construction material, it is necessary to study the performance of geopolymer concrete in various structural applications. The previous research on fly ash-based geopolymer concrete studied various short-term and long-term properties. Various mix design parameters influencing the strength of geopolymer concrete were investigated. It was shown that heat-cured geopolymer concrete possesses high compressive strength, undergoes low drying shrinkage and moderately low creep, and shows good resistance aggressive agents such as sulfate and acid [1]. Geopolymer concrete showed good bond strength with reinforcing steel which is necessary for its function as a composite material in reinforced concrete [10]. Steel reinforced geopolymer concrete beams and columns showed similar behavior to that of OPC 
concrete members [12-14]. The existing methods of the design codes were shown to be adequate for the design of geopolymer concrete members. Therefore, fly ash geopolymer is considered as a viable alternative binder for concrete elements such as beams, columns, slabs, walls, footings and other similar structural members.

Possessing adequate fire endurance is of utmost importance for a construction material in order to ensure safety of life and property. Materials with high fire endurance are especially required in areas prone to accidental fire and in structures with high level of importance such as high rise buildings, tunnels, buildings storing hazardous materials, nuclear facilities etc. Assessment of structures after a fire starts with the observation of cracking and spalling since these aspects significantly affect the load bearing capacity of structures. Residual strength of a material after fire exposure indicates the extent of remaining strength, its suitability for further usage and the need for repair. Therefore, comparison of the cracking and spalling damages, and residual strengths of different materials are used to compare their performances in a fire.

Combustibility of geopolymer fibre composites was studied by Lyon et al [15]. It was shown that the maximum temperature capability of carbon fibre reinforced geopolymer composite was more than $800{ }^{\circ} \mathrm{C}$. This was shown to be much higher than the capabilities of some other similar materials. Compressive strength of geopolymer concrete cylinders was found to increase when tested in the exposure of fire at $800{ }^{\circ} \mathrm{C}$ [16]. Foamed porous fly ash geopolymer paste samples were shown to have increased compressive strength after exposure up to $1000{ }^{\circ} \mathrm{C}$ [17]. Kong and Sanjayan [18] studied the effects of high temperature heat on geopolymers exposed up to $800{ }^{\circ} \mathrm{C}$. It was shown that metakaolin based geopolymers and their composites remained stable up to $600{ }^{\circ} \mathrm{C}$, whereas OPC binders experienced a rapid deterioration in compressive strength at around $300{ }^{\circ} \mathrm{C}$. It was also shown that geopolymer paste samples gained strength by 53\%, however identical formulation of composites combined with aggregates experienced a 65\% decrease in strength. The decrease in strength was attributed to the incompatibility between the thermal expansion of the aggregate and that of geopolymer paste. While aggregates expanded by $1.2-2.5 \%$, the geopolymer paste 
retracted by $1.6 \%$ at $800{ }^{\circ} \mathrm{C}$. This incompatibility in the thermal expansions of aggregate and paste resulted in internal damage of concrete and thus reduced the strength.

Previous studies [19, 20] on fly ash geopolymer concrete cylinders after fire exposure showed that residual strength was higher than the original strength for relatively low temperature such as up to $200{ }^{\circ} \mathrm{C}$. Then residual strength decreased with further increase in fire temperature. However, the strength retained by geopolymer concrete cylinders was higher than that by OPC concrete specimens up to $600{ }^{\circ} \mathrm{C}$. The strength loss of geopolymer concrete cylinders exposed to high temperature heat such as 800 to $1000{ }^{\circ} \mathrm{C}$ was similar to that of OPC concrete cylinders.

These previous studies were limited to the tests on small cube or cylinder specimens subjected to high temperature heat on all sides of the specimens. No study has been conducted to investigate the damages occurred in larger geopolymer concrete specimens reinforced with steel bars and strength retained by reinforced elements after a fire exposure. It is necessary to investigate the extent of damage and residual strength of steel reinforced geopolymer concrete elements at high temperature since real structures are mostly made of reinforced concrete members. The presence of steel and the number of sides of a specimen exposed to fire can have significant influence on the damage and strength loss. For example, the distribution of temperature inside a wall exposed to fire on one side will be different from that exposed to fire on both sides. This paper presents a study on the damages and residual strength of reinforced fly ash based geopolymer concrete panels exposed to standard ISO 834 [21] fire which is commonly used for testing of building materials. OPC and geopolymer concrete panels were exposed to fire on one side for two hours and then cooled down to normal temperature. Cracking and spalling damages in the two types of concrete specimens were inspected and the post-fire strengths were determined using compression tests. The behaviours of geopolymer concrete panels are compared with those of traditional OPC concrete panels.

\section{Materials and methods}


118 Experimental work was carried out in the laboratory to study the behaviour of steel 119 reinforced panels of OPC and geopolymer concretes exposed to high temperature fire. The 120 panels were of different thickness with the same amount of reinforcement. They were 121 exposed to standard fire for two hours and then cooled down to room temperature by turning 122 off the furnace. The transfer of heat through the specimens was recorded by using 123 thermocouples. The damages in terms of cracking and spalling of the specimens were 124 observed during fire exposure and after cooling down. The specimens were loaded to failure 125 in concentric compression in order to study the failure behaviour and determine the strength 126 retained by them after the fire exposure.

\subsection{Materials}

129 Concrete was mixed in the laboratory for casting of the test specimens. General purpose 130 Portland cement was used for OPC concrete specimens and commercially available class F 131 (ASTM 618) [22] fly ash was used to manufacture the geopolymer concrete specimens. 132 Percentage of the fly ash passing through a $45 \mu$ sieve was $75 \%$ and its loss on ignition was $1330.6 \%$. The chemical compositions of cement and fly ash used in making the specimens are 134 given in Table 1. The alkaline liquids for geopolymer concrete were sodium hydroxide and 135 sodium silicate solutions. Commercial sodium hydroxide pellets were dissolved in normal 136 tap water to make $14 \mathrm{M}$ solution. The readily available commercial sodium silicate solution 137 had a chemical composition of $14.7 \% \mathrm{Na}_{2} \mathrm{O}, 29.4 \% \mathrm{SiO}_{2}$, and $55.9 \%$ water by mass. Both 138 the liquids were mixed together before adding to the fly ash and aggregates. The coarse 139 aggregates were 7,10 and $20 \mathrm{~mm}$ nominal size crushed granite. The fine aggregate was river 140 sand. The aggregates were prepared to SSD condition before mixing of the concrete. Tap 141 water was used in mixing of the concretes. The mixture proportions of OPC and geopolymer 142 concrete are given in Table 2. The mixtures were designed to obtain similar compressive 143 strengths. The steel reinforcement of the test panels was a single layer of $500 \mathrm{MPa}$ normal 144 ductility deformed bars in both directions. 
Table 1 Chemical compositions of cement and fly ash (mass \%)

\begin{tabular}{cllllllllll}
\hline Compounds & $\mathrm{SiO}_{2}$ & $\mathrm{Al}_{2} \mathrm{O}_{3}$ & $\mathrm{Fe}_{2} \mathrm{O}_{3}$ & $\mathrm{CaO}$ & $\mathrm{Na}_{2} \mathrm{O}$ & $\mathrm{K}_{2} \mathrm{O}$ & $\mathrm{TiO}_{2}$ & $\mathrm{MgO}$ & $\mathrm{P}_{2} \mathrm{O}_{5}$ & $\mathrm{SO}_{3}$ \\
\hline Cement & 21.1 & 4.7 & 2.7 & 63.6 & 0.5 & - & - & 2.6 & - & 2.5 \\
Fly Ash & 50.8 & 26.9 & 13.5 & 2.05 & 0.33 & 0.57 & 1.57 & 1.33 & 1.46 & 0.31
\end{tabular}

147

148 Table 2 Mixture proportions of concrete $\left(\mathrm{kg} / \mathrm{m}^{3}\right)$

\begin{tabular}{|c|c|c|c|c|c|c|c|c|c|}
\hline \multirow[t]{2}{*}{ Mix } & \multirow[t]{2}{*}{ Cement } & \multirow{2}{*}{$\begin{array}{l}\text { Fly } \\
\text { ash }\end{array}$} & \multirow[t]{2}{*}{ Water } & \multirow{2}{*}{$\begin{array}{l}\text { Sodium } \\
\text { hydroxide }\end{array}$} & \multirow{2}{*}{$\begin{array}{l}\text { Sodium } \\
\text { silicate }\end{array}$} & \multirow[t]{2}{*}{ Sand } & \multicolumn{3}{|c|}{ Coarse aggregate } \\
\hline & & & & & & & $7 \mathrm{~mm}$ & $10 \mathrm{~mm}$ & 20 \\
\hline OPC & 385 & - & 205 & - & - & 616 & 412 & 240 & 492 \\
\hline GPC & - & 408 & 55 & 41 & 103 & 554 & 462 & 277 & 554 \\
\hline
\end{tabular}

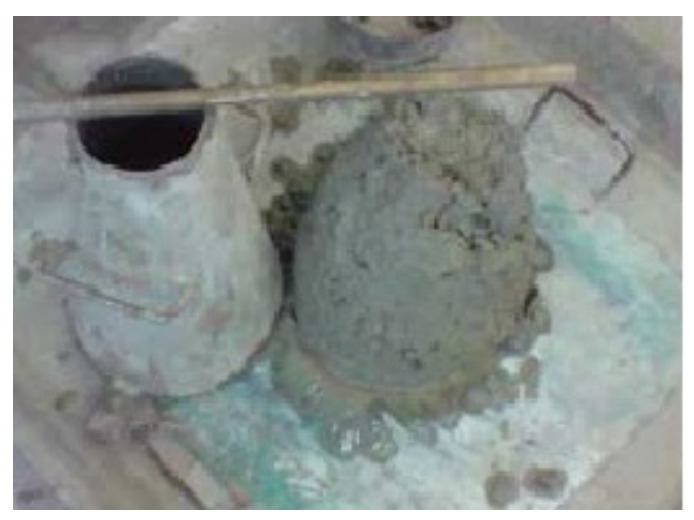

151 152 Figure 1(a). Slump of OPC concrete

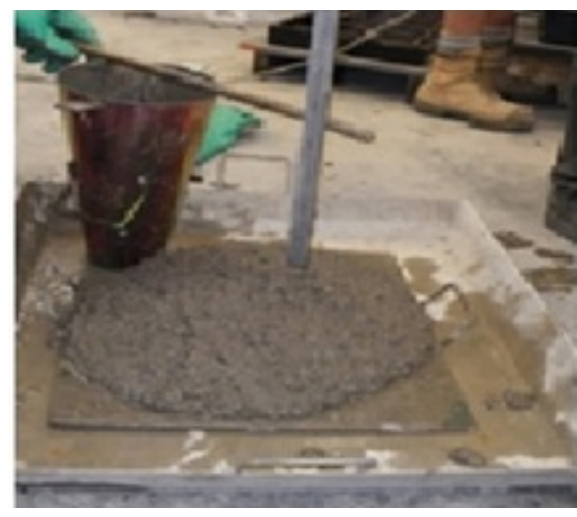

Figure 1(b). Slump of geopolymer concrete

\section{$153 \quad 2.2$ Casting of test specimens}

154 Concrete was mixed in the laboratory in a pan type mixer. Workability of fresh concrete was 155 determined by using standard slump test immediately after mixing the concrete. Slump tests 156 of OPC and geopolymer concrete are shown in Figures 1(a) and 1(b) respectively. The slump 157 of OPC concrete varied between 90 and $120 \mathrm{~mm}$ and that of geopolymer concrete varied 158 between 200 and $250 \mathrm{~mm}$. Both concretes had reasonable workability and the specimens 
were cast with sufficient ease. Though geopolymer concrete had a much higher slump than the OPC concrete, they both needed the same level of vibration to compact the concrete. This is because of the relatively higher viscosity of the activator solution used in geopolymer concrete. The geopolymer concrete specimens were cured by using steam and the OPC concrete specimens were cured by spraying water.

The test panel specimens were $500 \mathrm{~mm} \times 500 \mathrm{~mm}$ in size. Three OPC concrete panels and three geopolymer concrete panels were cast. Thicknesses of the panels were 125, 150 and $175 \mathrm{~mm}$. The reinforcement consisted of three bars of $12 \mathrm{~mm}$ diameter in each direction, distributed in the mid-depth of the section. The panels were compacted by using an electrically operated concrete vibrator. Casting of typical geopolymer concrete test panels are shown in Figure 2. A thermocouple was inserted in the centre of the panel to a depth of $25 \mathrm{~mm}$ from the top surface to measure the transfer of heat through the specimen when the opposite face would be exposed to fire. The geopolymer concrete panels were steam cured immediately after casting at $60{ }^{\circ} \mathrm{C}$ for 24 hours and then left in ambient condition until testing. The OPC concrete panels were cured by covering with hessians and spraying water for 14 days after casting. Accompanying standard $100 \mathrm{~mm} \times 200 \mathrm{~mm}$ cylinders were cast together with the test panels in order to determine compressive strength of concrete. The cylinders were cured in the same condition as the test panels.

\subsection{Method of testing}

The specimens were exposed to fire at 28 days after casting. Figure 3 shows a test panel set in the furnace for fire exposure. The furnace was turned on and the flame was increased by controlling the flow of gas. The face of the panel inside the furnace was exposed to fire and the opposite face was exposed to room temperature. This condition of heating is considered as the most critical for damage of the concrete by differential temperature between the heated face and the unheated face. The gaps between the test panel and the furnace were closed so that heat of the fire could not reach the unheated face of the panel. The geopolymer and OPC concrete specimens were exposed to fire in the same way. The fire in the furnace was controlled to achieve the heating rate recommended in the standards for fire test of building 
189 materials [21, 23]. The heating rate recommended in the ISO 834 [21] standard is given by 190 Equation 1.

191

$192 T_{t}=T_{0}+345 \log _{10}(8 t+1)$

193 Where $T_{t}$ is furnace temperature $\left({ }^{\circ} \mathrm{C}\right.$ ) at time $\mathrm{t}$ (minutes) and $T_{0}$ is the initial furnace 194 temperature $\left({ }^{\mathrm{O}} \mathrm{C}\right)$.

195 The temperature of the air inside the furnace was measured by an in-built thermocouple in 196 the furnace and that at $25 \mathrm{~mm}$ depth from the unheated face of the test panel was measured 197 by the thermocouple inserted in the specimen during casting. The furnace was turned off 198 after heating the specimens for two hours and the specimens were then left to cool down 199 normally to room temperature leaving the door of the furnace open. After cooling down to 200 room temperature, the specimens were tested under concentric compression using a universal 201 testing machine. The compression test of a panel is shown in Figure 4. The panels were 202 loaded to failure and the test failure loads were recorded.

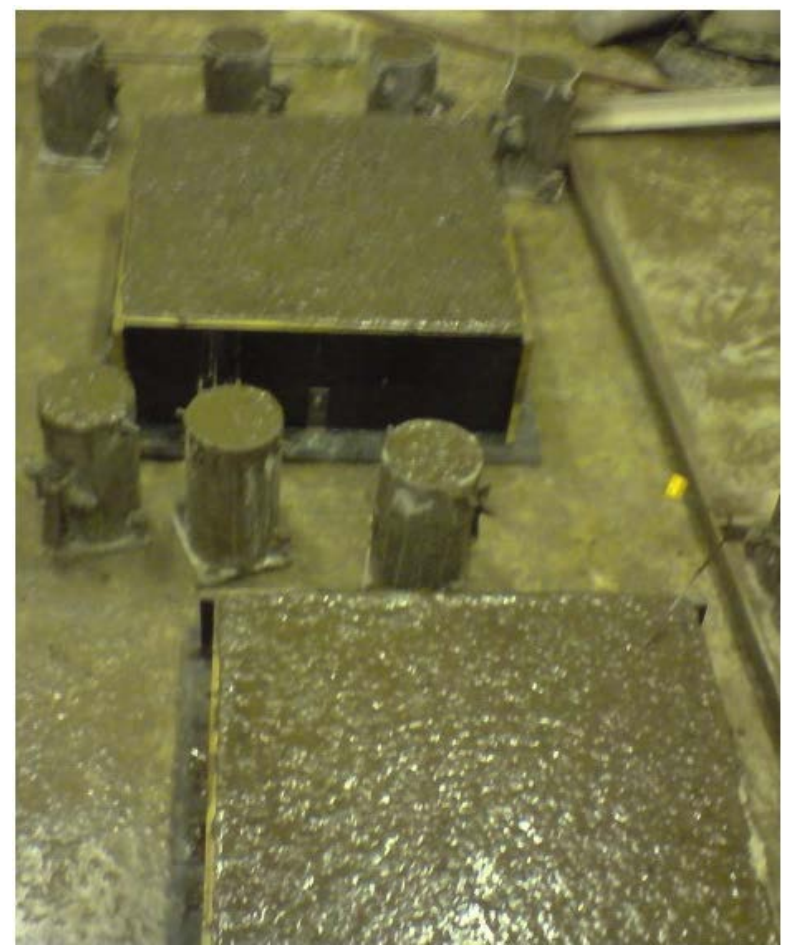

Figure 2. Casting of the geopolymer concrete test panels 


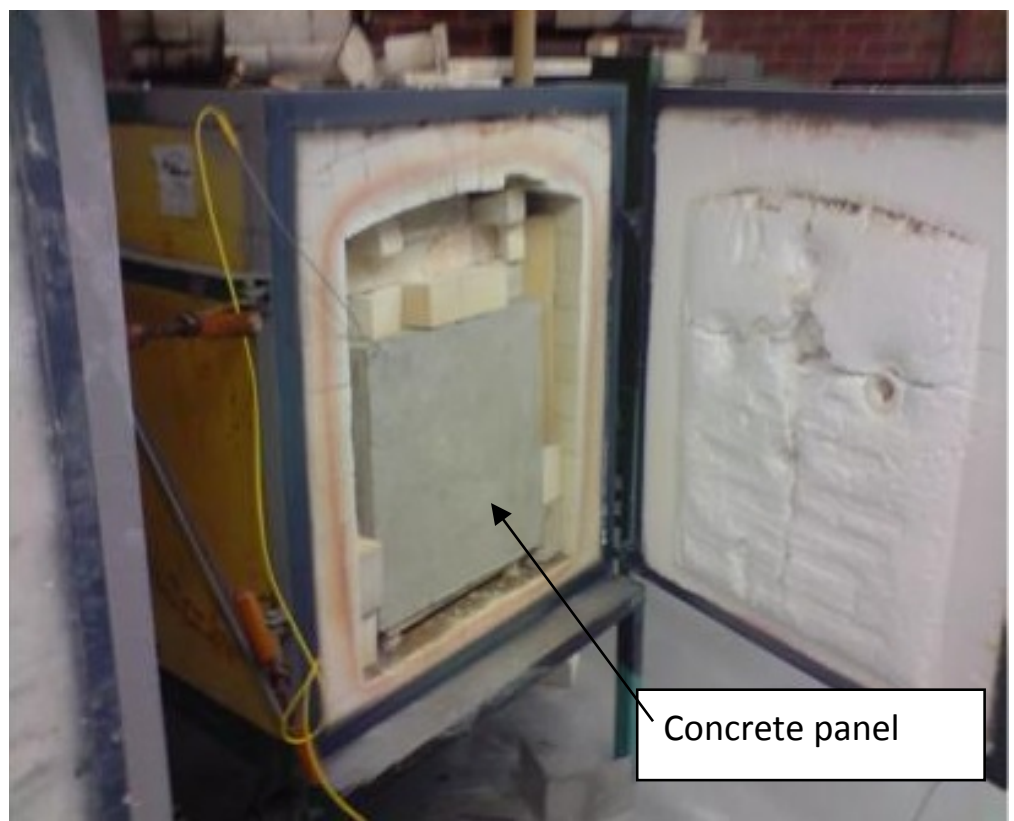

Figure 3. A concrete test panel set for fire exposure

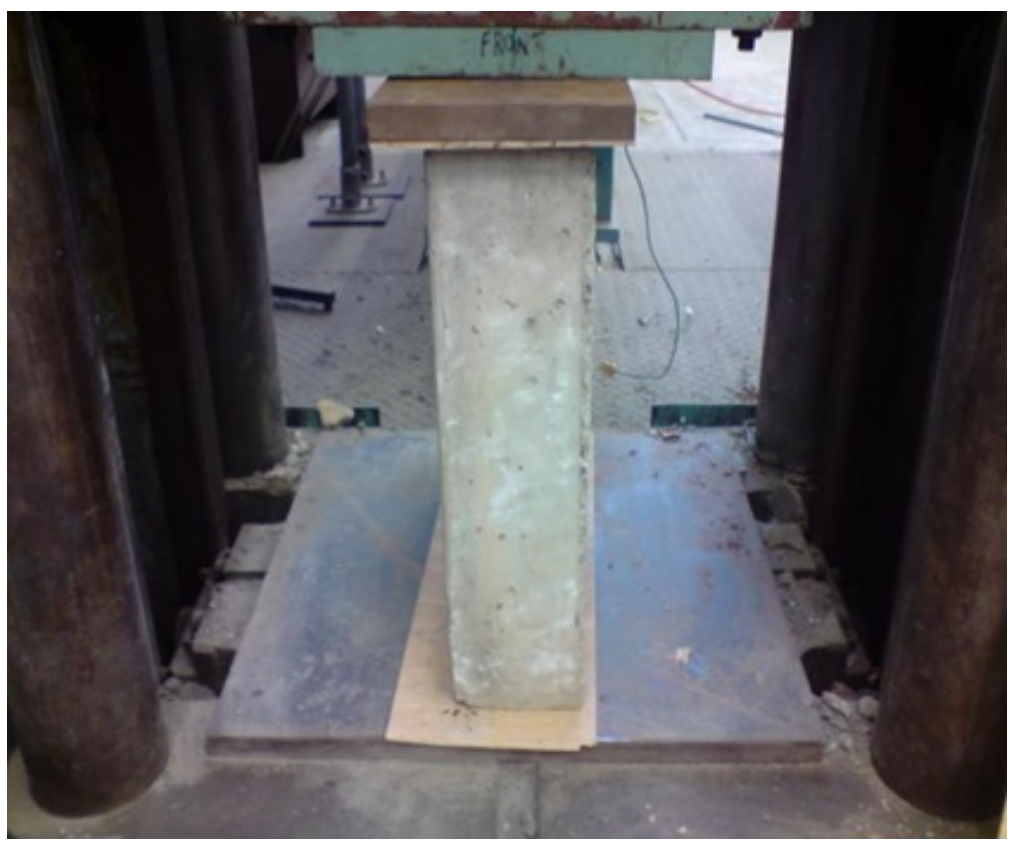

Figure 4. Post-fire compression test of a concrete panel 
211

212

213

214

215

216

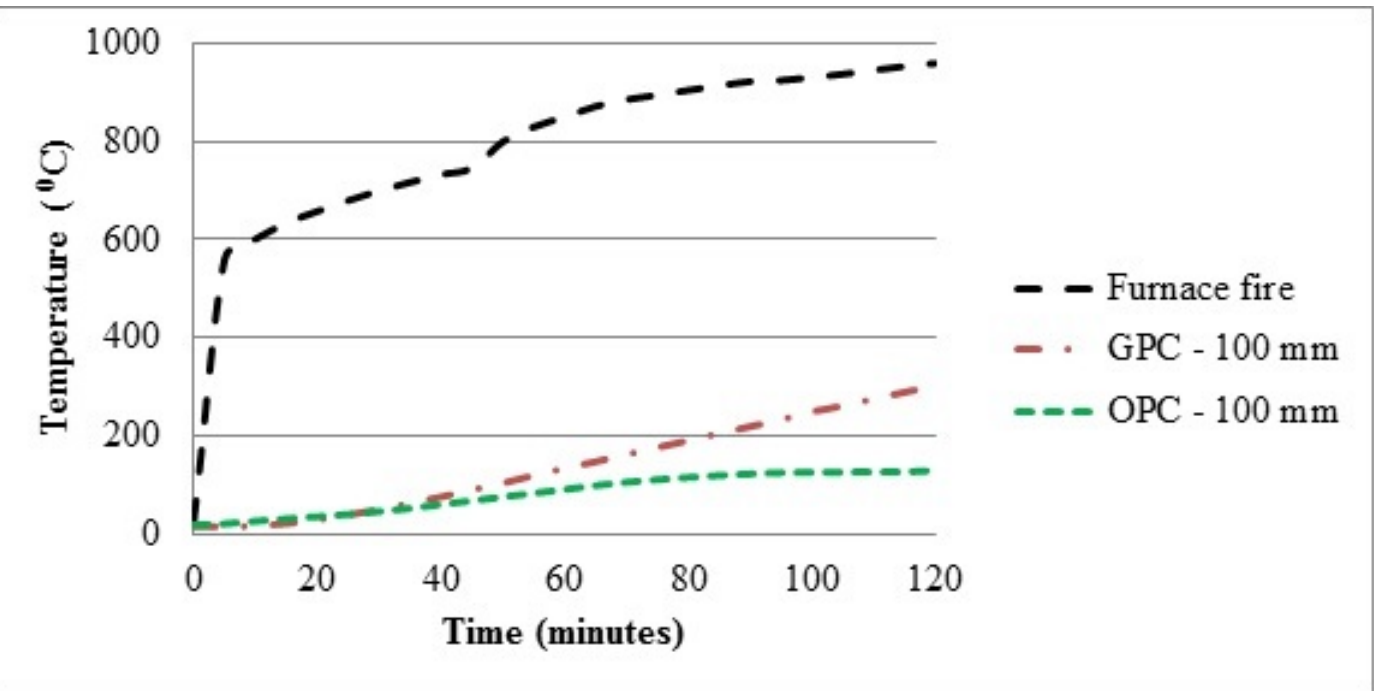

Figure 5. Temperature at $100 \mathrm{~mm}$ depth in the $125 \mathrm{~mm}$ thick panels

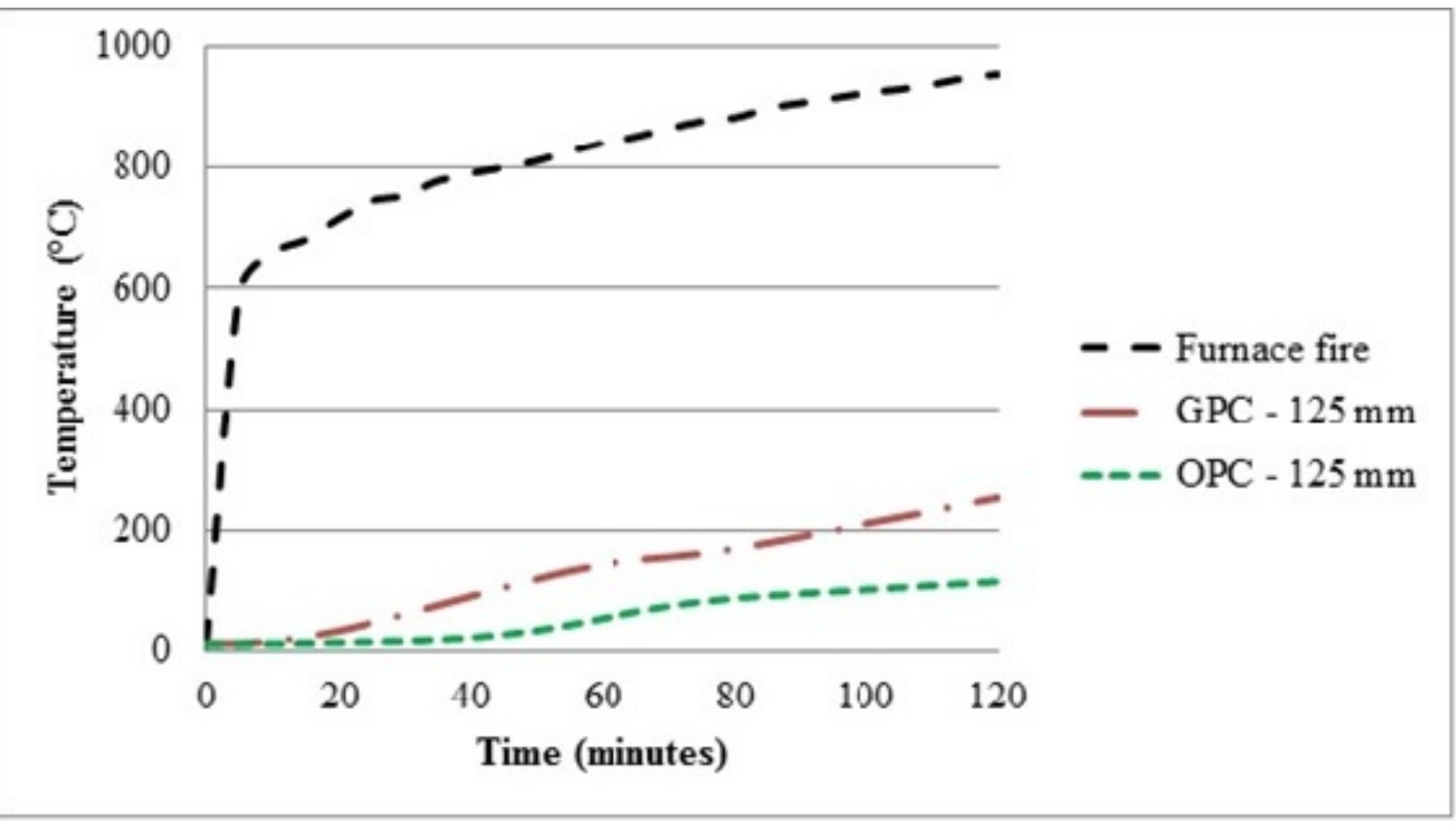

Figure 6. Temperature at $125 \mathrm{~mm}$ depth in the $150 \mathrm{~mm}$ thick panels 


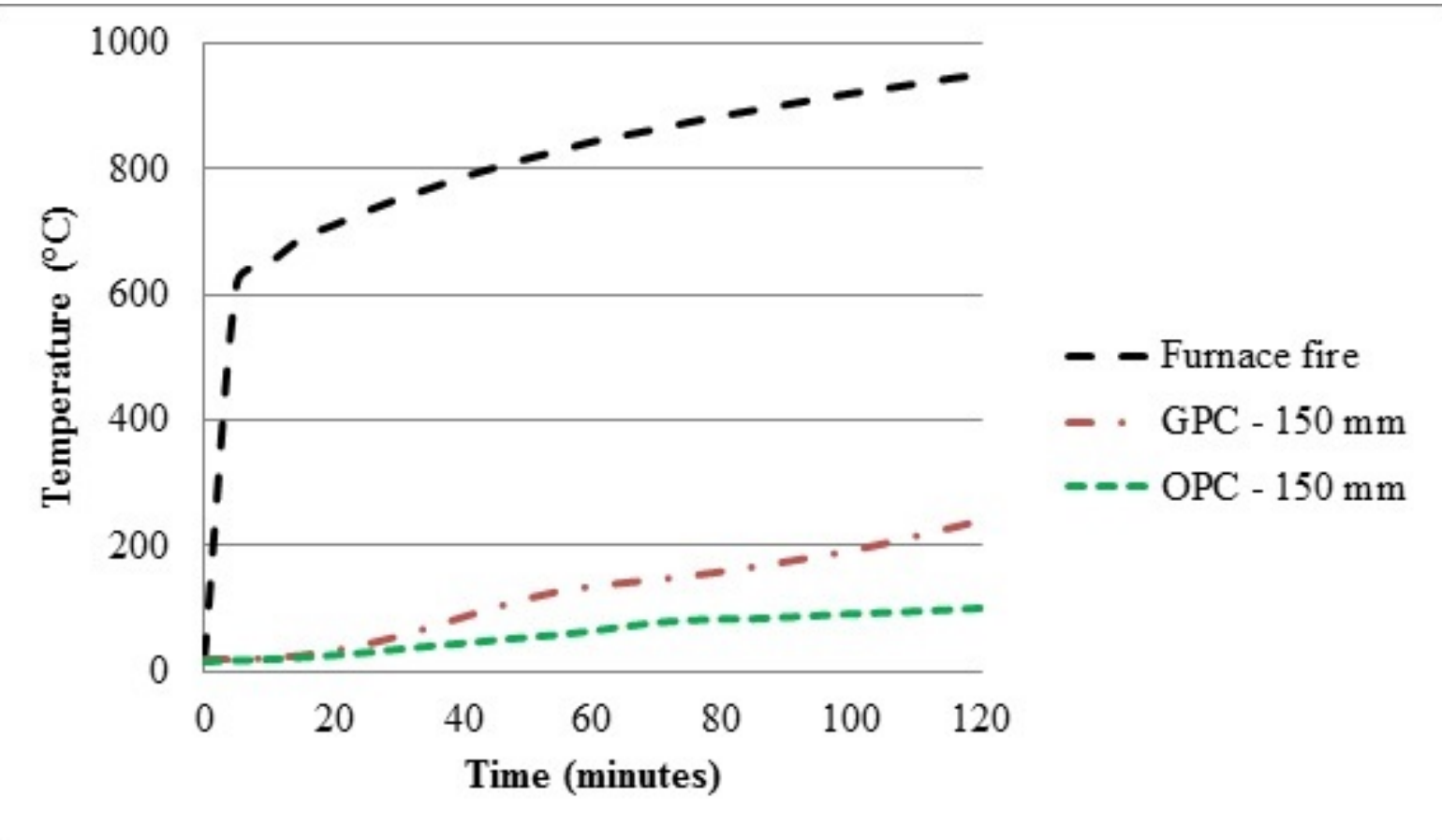

217

218

219

220

221

222

223

224

225

226

227

228

229

230

231

232

233

Figure 7. Temperature at $150 \mathrm{~mm}$ depth in the $175 \mathrm{~mm}$ thick panels

\section{Test results and discussion}

\subsection{Transfer of heat inside concrete panels under fire exposure}

The temperature-time curves of the fire inside the furnace during the 2 hours of fire exposure of the 125, 150 and $175 \mathrm{~mm}$ panels are shown in Figures 5, 6 and 7 respectively. The increase of temperature with time at $25 \mathrm{~mm}$ depth from the unheated face of the panels is also plotted in these figures. As shown in Figure 5, the temperatures measured at the end of the heating period in the $125 \mathrm{~mm}$ geopolymer and OPC concrete panels were 302 and 129 ${ }^{\circ} \mathrm{C}$, respectively, when the furnace temperature was $960{ }^{\circ} \mathrm{C}$. The highest temperatures in the $150 \mathrm{~mm}$ panels were 253 and $115{ }^{\circ} \mathrm{C}$ in the geopolymer and OPC concrete specimens, respectively, as shown in Fig 6. Similarly, the maximum temperatures in the $175 \mathrm{~mm}$ panels were 228 and $101{ }^{\circ} \mathrm{C}$ for the geopolymer and OPC concrete panels, respectively (Figure 7). As expected, temperature near the unheated face decreased with the increase of the panel thickness in both types of concrete. 
234 Comparing the temperature-time curves of the OPC and geopolymer concrete panels in each

235 figure, it can be seen that the temperature at a given time was higher in the geopolymer concrete panel than in the OPC concrete panel of the same thickness. Therefore, the geopolymer concrete panels showed a higher thermal conductivity than the OPC concrete panels at high temperature. Similar behaviour was also observed previously in the tests of cylinder specimens exposed to fire from all directions [20]. Subaer and van Riessen [24] measured a higher thermal conductivity value of hardened geopolymer paste than OPC paste samples. This higher thermal conductivity resulted in a a fastre travel of heat and smaller thermal gradient in the geopolymer concrete panels than in the OPC concrete panels. Thus, it can be said that the heat transfer rate of fly ash geopolymer concrete is generally higher than OPC concrete when exposed to the high temperature heat of fire.

\subsection{Damage of test specimens by cracking and spalling}

The typical cracks developed on the fire exposed face of the OPC concrete panels after 2 hours of fire exposure are shown in Figures 8 (a) and 8 (b). The typical cracks developed in a geopolymer concrete specimen are shown in Figure 9. It can be seen from these figures that there were cracks in the specimens of both types of concrete. However, relatively wider cracks were observed in the OPC concrete panels as shown in Figure 8 (b). The widths of the cracks in geopolymer concrete panels were relatively small as shown in Figure 9. As shown in Figure 8 (a), the 125-mm OPC concrete panel also suffered by spalling of concrete from a corner. No such spalling was observed in any of the geopolymer concrete panels. Similar spalling was also observed in some OPC concrete cylinders with no spalling of the geopolymer concrete cylinders of the previous tests [20]. The relatively less damage in the geopolymer concrete panels than in the OPC concrete panels is attributed to the smaller temperature differential in geopolymer concrete panels, as shown in Figures 5 to 7. The colour of the geopolymer concrete changed to red after the exposure to fire. This is attributed to the presence of high iron content of the fly ash used to make the geopolymer concrete. As the distance increased from the fire exposed face inside the specimen, the redness gradually decreased with the decrease of temperature. 


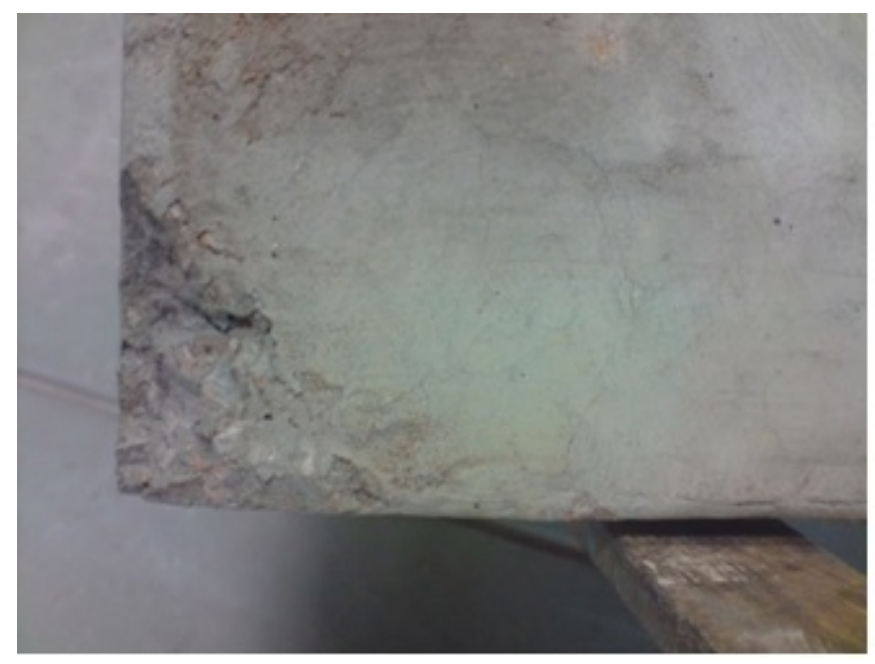

264 Figure 8(a). Corner spalling of the $125 \mathrm{~mm}$ thick OPC concrete panel

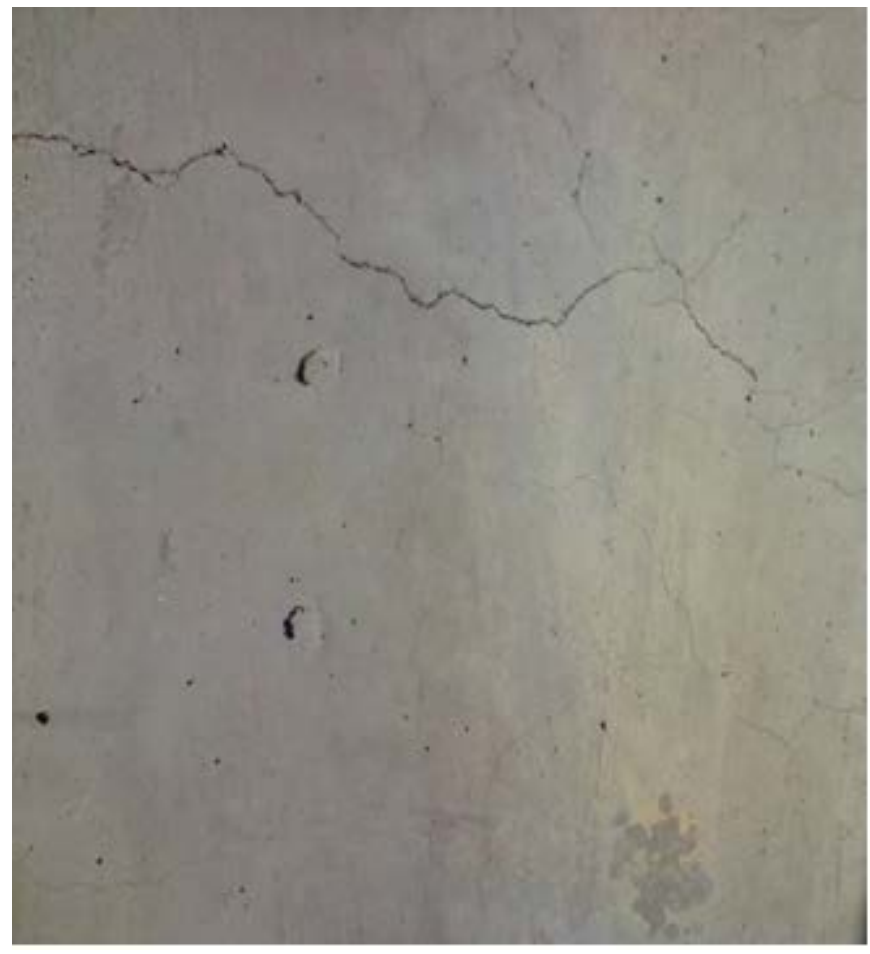

266 Figure 8(b). Typical cracks in the OPC concrete panels

267

268 


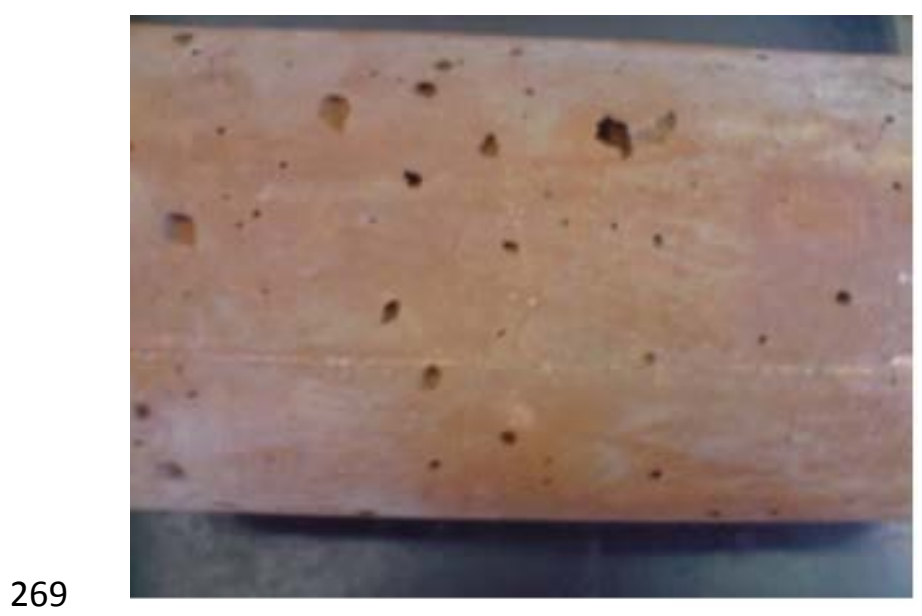

270 Figure 9. Typical cracks and colour change in the geopolymer concrete panels after fire 271 exposure
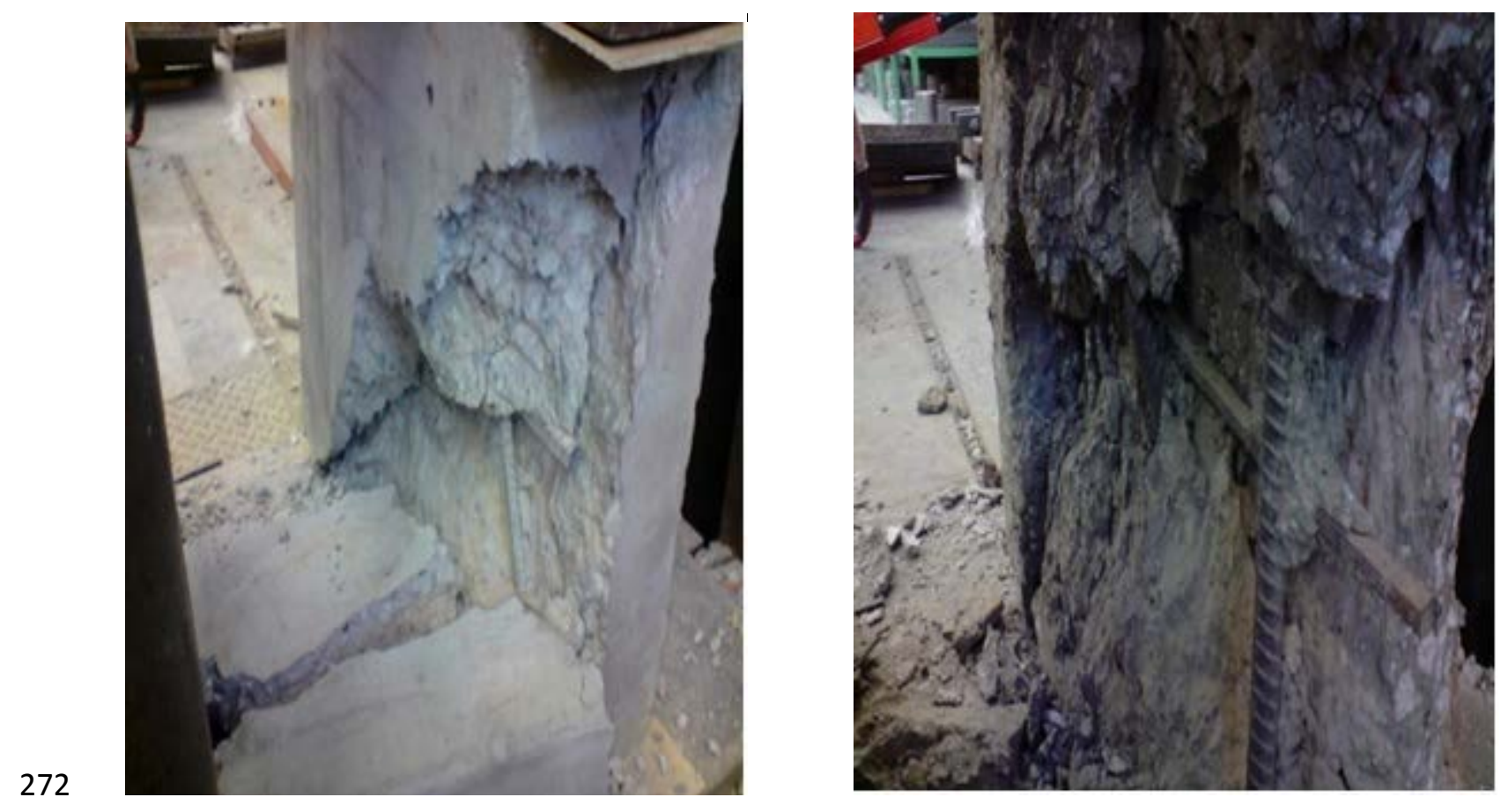

273 Figure 10(a). Failure of the $125 \mathrm{~mm}$ OPC concrete panel

Figure 10(b). Failure of the 125

274 mm GPC panel 
275

276 Figure 11(a). Failure of the150 mm OPC concrete panel

277 mm GPC panel

$$
\text { mon panel }
$$

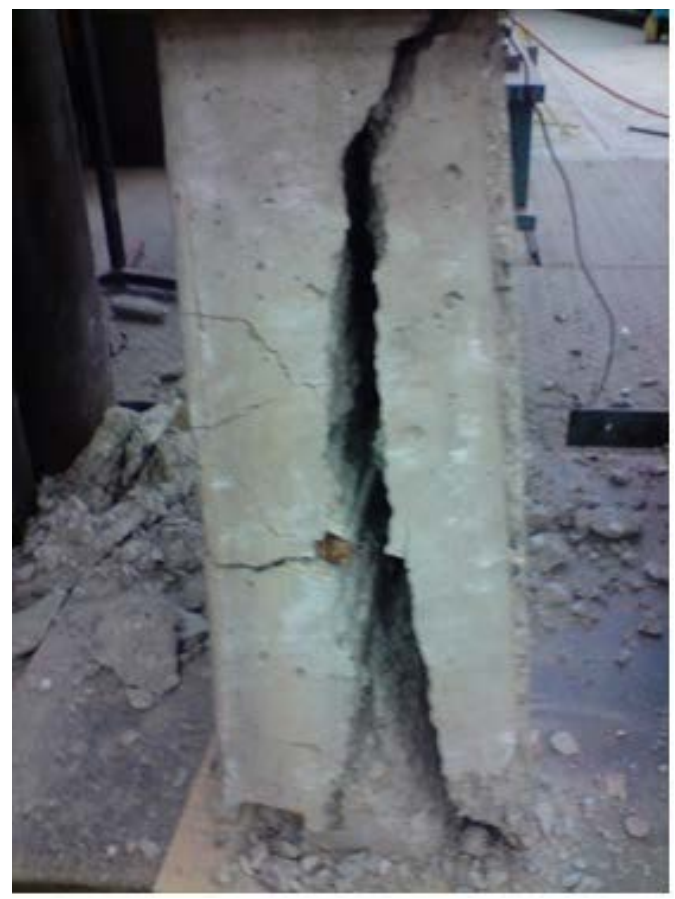
mm GPC panel
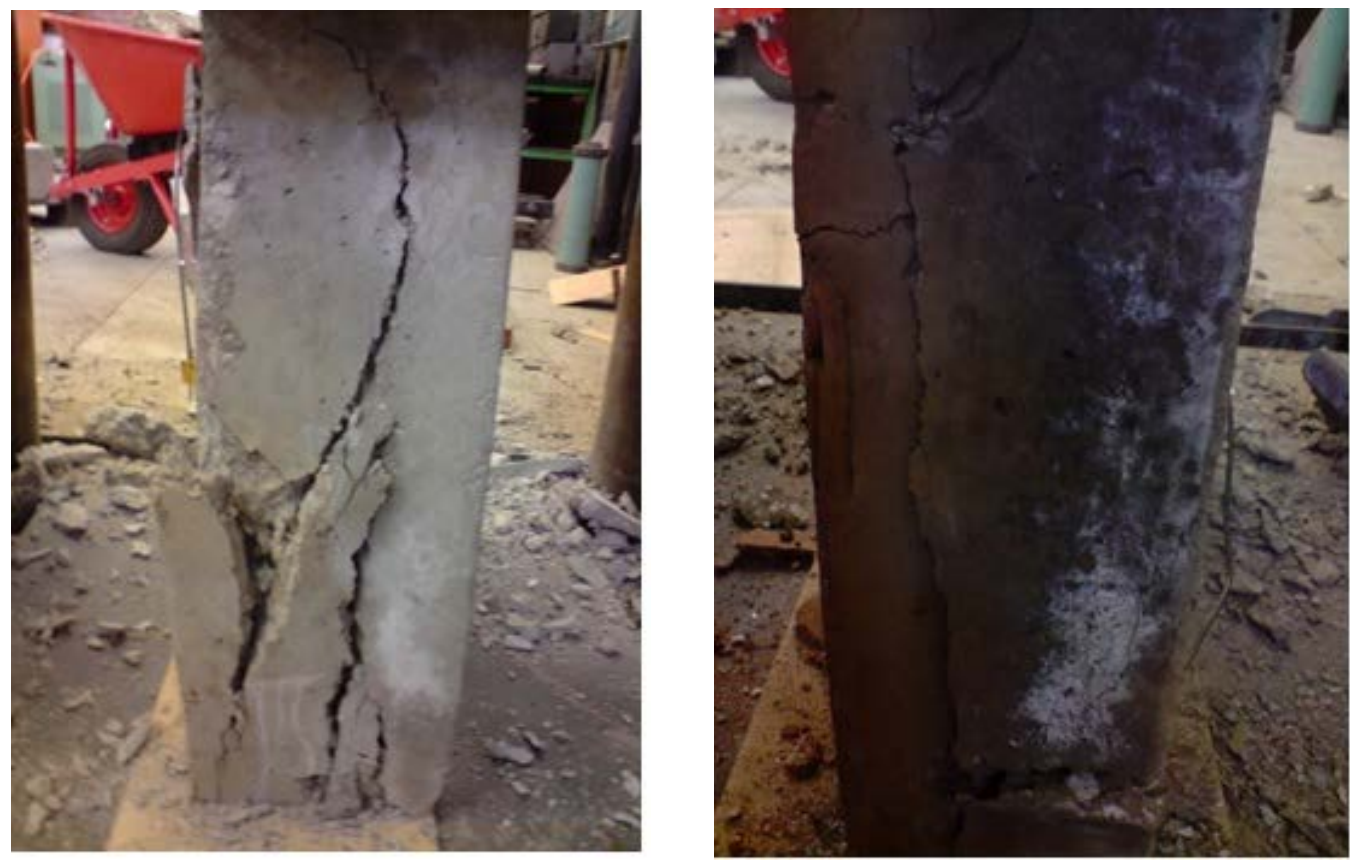

Figure 11(b). Failure of the 150

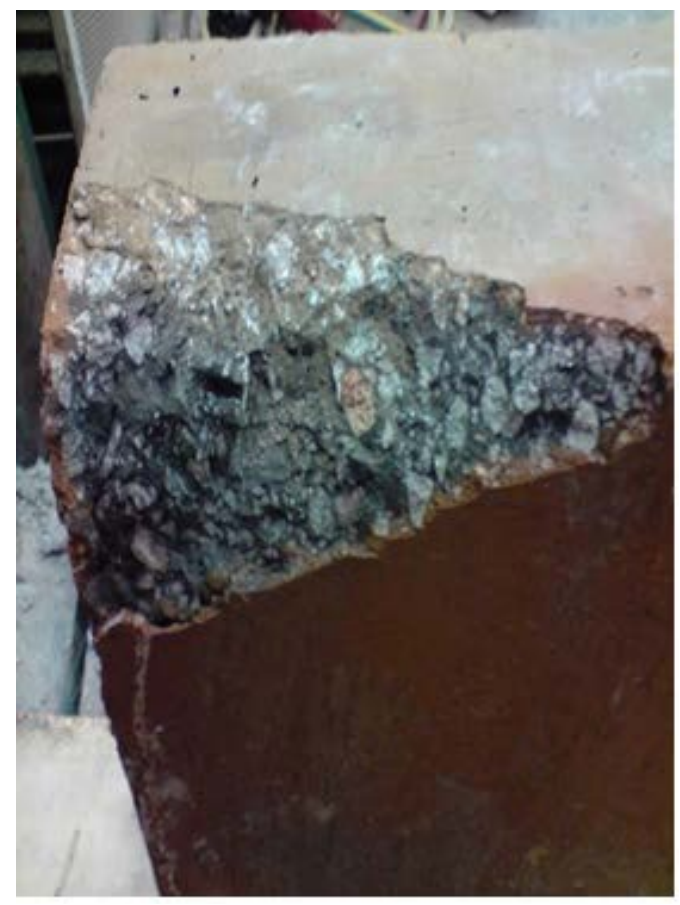

Figure 12(a). Failure of the $175 \mathrm{~mm}$ OPC concrete panel

Figure 12(b). Failure of the 175 


\subsection{Failure and residual strength of the panels in compression}

283 Numerous cracks were observed on the fire-exposed faces of both types of concrete panels

284 after cooling. This was expected because of the differential temperature in the panels across 285 the depth and because of thermal shocks in the heating and cooling stages. Typical failures of 286 the OPC and geopolymer concrete panels are shown in Figures 10 to 12. As shown in 287 Figures 10 (a) and (b), both $125 \mathrm{~mm}$ thick OPC and geopolymer concrete panels failed by 288 complete crushing of the concrete in the fire exposed side and bucking of the reinforcing 289 steel bars in the direction of fire exposure. Failure of the $150 \mathrm{~mm}$ thick geopolymer concrete 290 panel occurred mainly by splitting of concrete along a plane parallel to the direction of 291 loading, as shown in Figure 11(a). The OPC concrete panel of the same thickness occurred 292 by a combination of splitting and crushing of concrete in the fire-exposed side (Figure 293 11(b)). As shown in Figures 12 (a) and (b), the $175 \mathrm{~mm}$ thick geopolymer concrete panel 294 only damaged locally at the corner whereas the OPC concrete panel of the same thickness 295 failed by complete splitting of the concrete. The post-fire load capacities of the panels 296 obtained from the tests are given in Table 3.

297 The original load capacity of each panel before exposure to fire is calculated by using 298 Equation 2, considering the panel as a stocky reinforced concrete member under concentric 299 compression.

300

301

$P=f_{c m}\left(A_{g}-A_{s}\right)+A_{s} f_{y}$

302

303 304 305 where $P$ is the load capacity, $f_{c m}$ is the mean concrete compressive strength obtained from cylinders; $A_{g}$ is the gross cross-sectional area of the panel, $A_{s}$ is the area of reinforcing steel and $f_{y}$ is the yield strength of steel.

306

307

308

309

310

311 
312 Table 3 Load capacity of the test panels

\begin{tabular}{|c|c|c|c|c|c|c|}
\hline Concrete & $\begin{array}{c}\text { Panel } \\
\text { thickness } \\
\text { (mm) }\end{array}$ & $\begin{array}{c}\text { Cylinder } \\
\text { Compressive } \\
\text { strength, } f_{c m} \\
\quad(\mathrm{MPa})\end{array}$ & $\begin{array}{c}\text { Original } \\
\text { panel } \\
\text { strength } \\
\text { (Eq. 2), } \\
\text { kN }\end{array}$ & $\begin{array}{c}\text { Post-fire } \\
\text { panel } \\
\text { strength } \\
\mathrm{P}_{\text {test }}(\mathrm{kN})\end{array}$ & $\begin{array}{c}\text { \% strength } \\
\text { retained, } \\
\mathrm{P}_{\text {test }} / \\
\mathrm{P}_{\text {original }}\end{array}$ & $\begin{array}{l}\text { Mean \% } \\
\text { strength } \\
\text { retained }\end{array}$ \\
\hline \multirow[t]{3}{*}{ OPC } & 125 & 50 & 3278 & 1645 & 50 & \multirow[t]{3}{*}{51.6} \\
\hline & 150 & 45 & 3529 & 1873 & 53 & \\
\hline & 175 & 46 & 4179 & 2185 & 52 & \\
\hline \multirow[t]{3}{*}{ GPC } & 125 & 46 & 3029 & 2146 & 71 & \multirow[t]{3}{*}{65.6} \\
\hline & 150 & 50 & 3903 & 2368 & 61 & \\
\hline & 175 & 42 & 3830 & 2500 & 65 & \\
\hline
\end{tabular}

313

314

315

316

317

318

319

320

321

322

323

324

325

326

327

328

329

330

The mean cylinder compressive strength corresponding to each panel is given in the Table 3. For each test panel, area of the reinforcing steel was $339 \mathrm{~mm}^{2}$ and yield strength of steel was $500 \mathrm{MPa}$. The load capacities of the unheated panels calculated by Equation 2 are given in Table 3. The percentage of strength retained after exposure to fire is calculated for the panels by dividing the post-fire load capacity by the calculated original load capacity. The residual strengths of the two types of concrete panels of the same thickness are also compared in the plot of Figure 13. It can be seen from Table 3 and Figure 13 that the percentage of original strength retained by the geopolymer concrete panel is higher than that by the OPC concrete panel of the same thickness. The failure loads of the geopolymer concrete panels varied from $61 \%$ to $71 \%$ of the calculated original values and those of the OPC concrete panels were between $50 \%$ and $53 \%$ of the original strengths. The reason for higher percentage of strength retained by the geopolymer concrete panels is attributed to the smaller temperature differential between the heated and unheated faces than that of the OPC concrete panels. The smaller temperature differential has caused relatively less internal damage in the geopolymer concrete panels. It was shown in the previous study [20] that the residual strengths of cylinder specimens exposed to ISO 834 fire for 2 hours was 17\% and 12\% for geopolymer concrete and OPC concrete respectively. The results obtained for the reinforced concrete 
331 panels show similar trend to those for the cylinder specimens. However, the percentage 332 residual strengths of the reinforced concrete panels are much higher than those of the 333 cylinder specimens. This is because of the presence of steel reinforcement in the panels, their 334 larger size as compared to the cylinders and the difference in the exposure to fire.

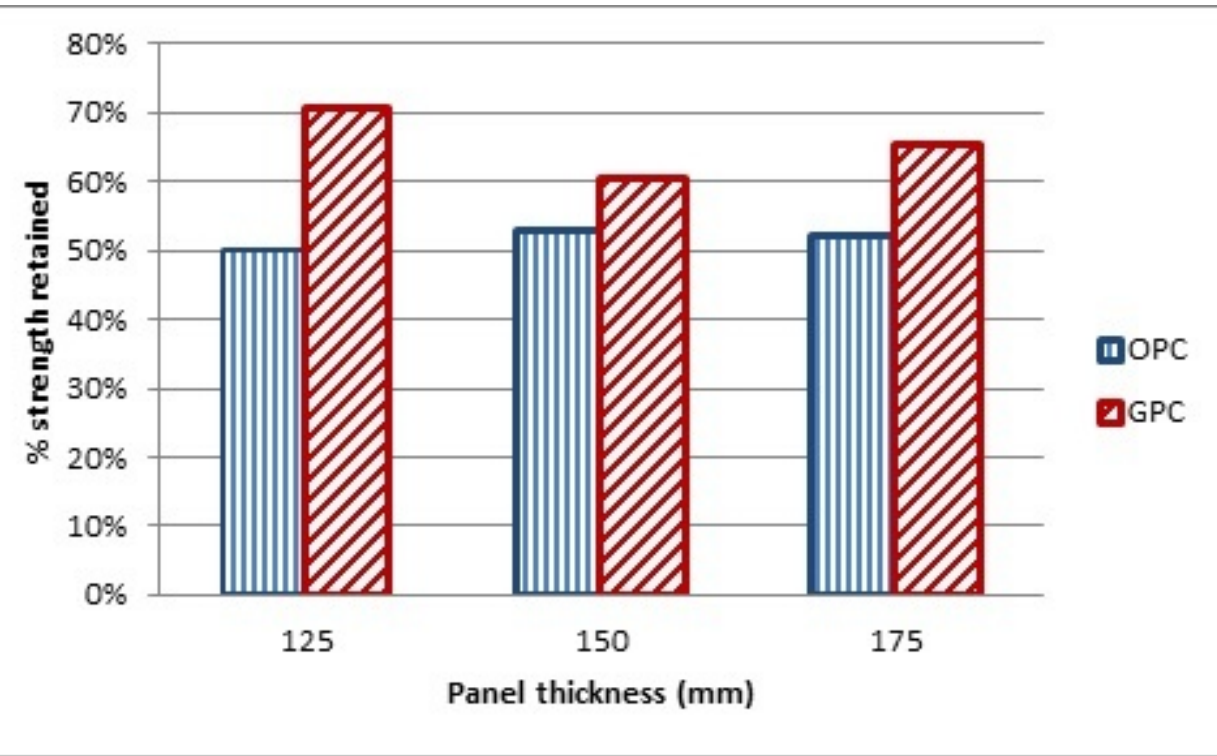

337 Figure 13. Residual strengths of the OPC concrete and GPC test panels

\section{Conclusions}

Six 500-mm square reinforced OPC and geopolymer concrete panels of 125, 150 and 175 mm thickness were exposed to fire of up to $960{ }^{0} \mathrm{C}$ temperature for two hours. The panels

342 were then cooled down and tested under compressive load. The heat transfer at high 343 temperature was generally faster in geopolymer concrete panel than in the OPC concrete 344 panel of same thickness. This resulted in smaller temperature differential in the geopolymer 345 concrete panels. The damages by cracking and spalling were less in the geopolymer concrete 346 panels than in the OPC concrete panels. Compression tests of the panels after cooling down 347 to room temperature showed that the geopolymer concrete panels retained higher percentage 348 of strength than the OPC concrete panels. The mean value of the percentage strength retained 349 by the geopolymer and OPC concrete panels was 66\% and 52\% respectively. The higher 350 residual strength of the reinforced geopolymer concrete specimens is attributed to the less 
351 internal damage because of the less temperature differential than in the OPC concrete 352 specimens. This shows the superior fire endurance of steel reinforced fly ash geopolymer 353 concrete elements than that of OPC concrete elements.

\section{Acknowlwdgements}

356 The authors gratefully acknowledge the utilisation of a furnace in the Department of Arts at 357 Curtin University, Western Australia for the experimental work.

\section{References}

1. Hardjito, D., Wallah, S. E., Sumajouw, D. M. J. and Rangan, B. V., "On the Development of Fly Ash-Based Geopolymer Concrete”, ACI Materials Journal, V. 101, No. 6, 2004, pp. 467-472.

2. Nath, P., Sarker, P. K., "Effect of GGBFS on Setting, Workability and Early Strength Properties of Fly Ash Geopolymer Concrete Cured in Ambient Condition”, Construction and Building Materials, V. 66, 2014, pp. 163-171.

3. Fernandez- Jimenez, A., Palomo, A., "Engineering properties of alkali-activated fly ash concrete”, ACI Materials Journal, 103, No. 2, 2006, pp.106-112.

4. Chindaprasirt, P., Chareerat, T. and Sirivivatnanon, V., "Workability and strength of coarse high calcium fly ash geopolymer”, Cement and Concrete Composites, V. 29, 2007, pp. 224-229.

5. Davidovits, J., “High-Alkali Cements for 21st Century Concretes”, Concrete Technology Past, Present and Future, ACI Special Publication, SP 144, 1994, pp. 383-398.

6. Bakharev, T., Sanjayan, J. and Cheng, Y., “Alkali activation of Australian slag cements” Cement and Concrete Research, V. 29, 1999, pp. 113-120.

7. Fernandez-Jimenez, A. Palomo, J. G. and Puertas, F., “Alkali activated slag mortars: mechanical strength behavior”, Cement and concrete Research, V. 29, 1999, pp. 1313-1321.

8. Deb, P., Nath, P., Sarker, P. K., “The Effects of Ground Granulated Blast Furnace Slag Blending with Fly Ash and Activator Content on the Strength and Workability of 
Geopolymer Concrete Cured at Ambient Temperature”, Materials and Design, V. 62, 2014, pp. 32-39.

9. Nath, P., Sarker, P. K., "Use of OPC to improve setting and early strength properties of low calcium fly ash geopolymer concrete cured at room temperature”, Cement and Concrete Composites, V. 55., 2015, pp. 205 - 214.

10. Fernandez- Jimenez, A. and Palomo, A., "Composition and microstructure of alkali activated fly ash binder: effect of the activator”, Cement \& Concrete Research, 35, 2005, pp. 1984-1992.

11. Sarker, P. K., "Bond strength of Reinforcing Steel Embedded in Geopolymer Concrete”, Materials and Structures, V. 44, 2011, pp. 1021 - 1030.

12. Rahman, M., and Sarker, P. K., "Geopolymer Concrete Columns under Combined Axial Load and Biaxial Bending”, CONCRETE 2011 Conference, Oct 12-14, 2011: Perth, Western Australia: The Concrete Institute of Australia.

13. Sumajouw, D. M. J., Hardjito, D., Wallah, S. E., and Rangan, B. V., "Fly Ash-Based Geopolymer Concrete: Study of Slender Columns”, Journal of Materials Science, V. 42 No. 9, 2007, pp. 3124-3130.

14. Chang, E. H., Sarker, P. K., Lloyd, N. and Rangan, B. V., "Shear Behaviour of Reinforced Fly Ash-Based Geopolymer Concrete Beams”, Proceedings of the Concrete Institute of Australia $23^{\text {rd }}$ Biennial Conference, Adelaide, Australia, October 18 - 20, 2007, pp. $679-687$.

15. Lyon, R. E., Balaguru, P. N., Foden, A., Sorathia, U., Davidovits, J., Davidovics M., “Fire resistant aluminosilicate composites”, Fire and Materials, V. 21, 1997, pp. 61-73.

16. Shaikh, F. U. A. and Vimonsatit, V., "Compressive strength of fly ash based geopolymer concrete at elevated temperature”, Fire and Materials, 2014, DOI: 10.1002/fam.2240.

17. Abdullah, M. M. A. B., Jamluddin, L, Hussin, K., Bnhussain, N., Ghazali, C. M. R., Ahmad, M. I., "Fly ash porous material using geopolymerization process for high temperature exposure”, International journal of molecular sciences, V. 13, 2012, pp. 4388-4395. 
408 18. Kong, D. L. Y., and J. G. Sanjayan, "Damage behavior of geopolymer composites 409 exposed to elevated temperatures”, Cement and Concrete Composites, V. 30, No. 10, $410 \quad$ 2008, pp. 986-991.

411 19. Sarker, P. K. and de Meillon, T., “Geopolymer concrete after exposure to high 412 temperature heat” Recent Developments in Structural Engineering, Mechanics and 413 Computation, Zingoni A. (ed.), Millpress, Rotterdam, The Netherlands, 2007, pp. 1566 $414 \quad 1571$.

415 20. Sarker, P. K., Kelly, S. and Yao, Z. T., "Effect of fire exposure on cracking, spalling and 416 residual strength of fly ash geopolymer concrete”, Materials and Design, V. 63, 2014, $417 \quad$ pp.584-592.

418 21. International Standards Organisation, Fire Resistance Tests, Elements of Building 419 Construction (ISO 834), Switzerland, 1980.

420 22. ASTM Standards, Standard Specification for Coal Fly Ash and Raw or Calcined Natural $421 \quad$ Pozzolan for Use in Concrete (ASTM C 618 - 08), USA, 2008.

422 23. Australian Standard, Methods for Fire Tests on Building Materials, Components and $423 \quad$ Structures (AS 1530.4), Australia, 1997.

424 24. Subaer, van Riessen, A., "Thermo-mechanical and microstructural characterisation of 425 sodium poly (sialate-siloxo) (Na-Pss) geopolymers”, Journal of Materials Science, V. 42, 426 2007, pp. 3117-3123.

427 